\title{
Pengaruh Model Pembelajaran ExamplesNon Examples Berbantuan Alat Peraga terhadap Hasil Belajar IPA
}

\author{
Pratiwi ${ }^{1}$, A. A. Gede Agung ${ }^{2}$, I Gd. Margunayasa ${ }^{3}$ \\ $1,2,3$ Jurusan Pendidikan Guru Sekolah Dasar, Fakultas IImu Pendidikan \\ Universitas Pendidikan Ganesha \\ Singaraja, Indonesia \\ e-mail: pratiwitiwi133@gmail.com¹, agungtps2056@gmail.com², \\ igede.margunayasa@undiksha.ac.id ${ }^{3}$
}

\begin{abstract}
Abstrak
Permasalahan rendahnya hasil belajar IPA siswa kelas V di Gugus II Kecamatan Kubutambahan menjadi masalah utama dilakukannya penelitian ini. Rendahnya hasil belajar IPA terjadi karena karena pembelajaran masih berpusat pada guru dan siswa cenderung pasif. Oleh karena itu, penelitian ini dilakukan dengan tujuan untuk mengetahui pengaruh yang signifikan model pembelajaran examples non examples berbantuan alat peraga terhadap hasil belajar IPA siswa kelas V SD di Gugus II Kecamatan Kubutambahan Tahun Pelajaran 2017/2018. Populasi penelitian adalah siswa kelas V di SD Gugus II Kecamatan Kubutambahan Tahun Pelajaran 2017/2018 yang menerapkan KTSP berjumlah 187 siswa. Sampel penelitian yaitu siswa kelas V SD N 6 Kubutambahan berjumlah 28 siswa dan siswa kelas V SD N 2 Kubutamabahan berjumlah 30 siswa. Data hasil belajar IPA dikumpulkan dengan metode tes bentuk pilihan ganda. Data hasil penelitian tersebut dianalisis dengan teknik statistik deskriptif dan statistik inferensial (uji-t). Hasil penelitian menunjukkan bahwa: (1) rata-rata hasil belajar IPA kelompok eksperimen adalah 23,57 berada pada kategori sangat tinggi, (2) rata-rata hasil belajar IPA kelompok kontrol adalah 17,60 berada pada kategori tinggi, (3) Hasil uji hipotesis dengan teknik uji-t, diperoleh $t_{\text {hitung }}$ lebih besar dari $t_{\text {tabel }}(6,626>2,003)$. Berdasarkan hasil analisis data tersebut, dapat disimpulkan bahwa terdapat pengaruh yang signifikan model pembelajaran examples non examples berbantuan alat peraga terhadap hasil belajar IPA siswa kelas V SD di Gugus II Kecamatan Kubutambahan Tahun Pelajaran 2017/2018.
\end{abstract}

Kata Kunci: Alat Peraga, Examples Non Examples, Hasil Belajar IPA

\section{Abstract}

The problem of low science learning outcomes on the fifth-grade students in cluster two in Kubutambahan sub-district become the main problem of this research. The low science learning outcomes occur because learning is still teacher-centered and students tend to be passive. Because of that, this study should be conducted to know the significant examples of non-examples method it helps by props toward students science learning outcomes on the fifthgrade elementary school students in the cluster two in Kubutambahan sub-district in academic year 2017/2018. The population of this study was the students of the fifth-grade elementary school students in cluster two in Kubutambahan sub-district in the academic year 2017/2018 applying KTSP totaling 187 students. The sample of this study was the students of the fifth grade in SD N 6 Kubutambahan totaling 28 students and students of the fifth grade in SD N 2 Kubutambahan totaling 30 students. The process of data collection using the test method in the form of multiple choice. The data result of this study was analyzed by statistics descriptive technique and inferential statistics (uji-t). The result showed: (1) the average of science learning outcomes in experiment group were 23,57 which could be categorized very high, (2) the average of science learning outcomes in control group were 17,60 which could be categorized high, (3) the result of hypothesis test using uji-t technique, obtained $t_{\text {-hitung }}$ bigger then $t_{\text {tabel }}$ $(6,626>2,003)$. Based on result analysis data, it could be concluded that there was the effect of the significance examples non-examples method it helps by props toward students science learning outcomes on the fifth-grade elementary school students in the cluster two in Kubutambahan sub-district in academic year 2017/2018.

Keywords: Props, Examples Non-Examples, Science Learning Outcomes 


\section{Pendahuluan}

Pendidikan merupakan faktor yang penting dalam setiap kegiatan pembangunan, karena sasaran utamanya adalah peningkatan sumber daya manusia (SDM). Terkait dengan pentingnya pendidikan untuk meningkatkan kualitas SDM tergantung pada bagaimana pembelajaran dirancang dan dijalankan. Idealnya pembelajaran harus lebih didominasi oleh siswa. Siswa yang lebih banyak melakukan proses interaksi dalam kelas juga membutuhkan dukungan sarana di luar manusia yang disediakan guru dalam bentuk bahan cetakan atau digital yang disediakan dalam komputer. Menurut Djafar (2014) pendidikan yang mampu mendukung pembangunan di masa mendatang adalah pendidikan yang mampu mengembangkan potensi peserta didik, sehingga yang bersangkutan mampu menghadapi dan memecahkan masalah kehidupan yang dihadapinya. Pendidikan harus menyentuh potensi nurani maupun potensi kompetensi peserta didik. Konsep pendidikan tersebut terasa semakin penting ketika seseorang harus memasuki kehidupan di masyarakat dan dunia kerja, karena yang bersangkutan harus mampu menerapkan apa yang dipelajari di sekolah untuk menghadapi problema yang dihadapi dalam kehidupan seharihari saat ini maupun yang akan datang.

Proses pembelajaran yang demikian seharusnya yang terjadi pada pembelajaran IPA. Menurut Susanto (2013), IPA dapat dikalsifikasikan menjadi tiga bagian, yaitu IPA sebagai produk, IPA sebagai proses, dan IPA sebagai sikap ilmiah. IPA sebagai produk, yaitu kumpulan hasil penelitian yang telah ilmuan lakukan dan sudah membentuk konsep yang telah dikaji sebagai kegiatan empirik dan kegiatan analitik. IPA sebagai produk meliputi fakta-fakta, konsep, prinsip, hukum, dan teori-teori. IPA sebagai proses, yaitu sejumlah keterampilan untuk mengkaji fenomena alam dengan cara-cara tertentu untuk memperoleh ilmu dan pengembangan ilmu itu selanjutnya. Dengan keterampilan proses IPA, peserta didik dapat memelajari IPA sesuai dengan apa yang dilakukan oleh para ahli, yaitu melakukan pengamatan, klasifikasi, inferensi, merumuskan hipotesis, dan melakukan eksperimen. IPA sebagai sikap ilmiah, yaitu sikap yang perlu dikembangkan dalam pembelajaran melalui berbagai kegiatan ilmiah, seperti diskusi, penyelidikan, simulasi, atau kegiatan proyek. Hal ini dikarenakan sikap ilmiah akan membiasakan peserta didik berpikir secara ilmiah untuk menyelesaikan berbagai permasalahan yang dihadapi. Pembelajaran IPA sangat berperan dalam proses pendidikan dan juga perkembangan ilmu pengetahuan dan teknologi, karena IPA memiliki upaya untuk membangkitkan minat serta kemampuan manusia dalam mengembangkan ilmu pengetahuan dan teknologi serta pemahaman tentang alam semesta yang mempunyai banyak fakta yang belum terungkap dan masih bersifat rahasia sehingga hasil penemuannya dapat dikembangkan menjadi IImu Pengetahuan Alam yang baru dan dapat diterapkan dalam kehidupan sehari-hari. Berdasarkan hal tersebut, pembelajaran IPA harus bisa menitikberatkan pada suatu proses pengalaman langsung bagi diri siswa.

Pengalaman langsung yang dimaksud adalah pembelajaran IPA di sekolah dasar (SD) yang dilakukan dengan penyelidikan sederhana dan bukan hafalan terhadap kumpulan konsep IPA. Susanto (2013:171) menyatakan bahwa, "Siswa akan mendapat pengalaman langsung melalui pengamatan, diskusi, penyelidikan sederhana". Pembelajaran IPA di SD sebaiknya juga memberikan kebebasan kepada siswa untuk membuat atau menafsirkan suatu hal dalam kegiatan pembelajaran untuk merancang dan menemukan sesuatu secara mandiri, sehingga pembelajaran IPA di SD diharapkan mampu dipahami dengan baik oleh siswa karena siswa mampu bekerja dan berkarya menemukan suatu hal secara mandiri. Selain itu, pendidik juga harus mampu menggunakan berbagai model dan media pembelajaran agar peserta didik dapat melakukan kegiatan belajar dengan baik, karena peserta didik tidak hanya sebagai objek tetapi juga merupakan subjek dalam pembelajaran. Berdasarkan hal tersebut pembelajaran IPA di SD akan mencerminkan kegiatan yang kondusif dan menyenangkan.

Selama ini pembelajaran IPA di sekolah dasar pada umumnya masih menggunakan pembelajaran yang berpusat pada guru (teacher centered), siswa hanya berperan sebagai pendengar dan penerima semua informasi yang diberikan oleh guru. Pembelajaran IPA di sekolah lebih banyak menekankan pada produk IPA dibandingkan dengan proses IPA maupun sikap ilmiah siswa. Kebanyakan guru selalu melatih siswa untuk menjawab soal-soal IPA dan mengabaikan kegiatan-kegiatan yang membuat siswanya belajar bermakna. Menurut Suastra (2009), belajar bermakna yang dimaksud dalam pembelajaran IPA adalah siswa mampu memperoleh pemahaman berdasarkan apa yang dilihat, didengar, dirasakan, dan dialami oleh siswa. 
Dari hasil wawancara dengan enam guru mata pelajaran IPA di kelas $\mathrm{V}$ pada tanggal 8 Desember 2017 dan 9 Desember 2017 di SD Gugus II Kecamatan Kubutambahan yang menerapkan Kurikulum Tingkat Satuan Pendidikan (KTSP), didapatkan hasil sebagai berikut. (1) pembelajaran IPA di kelas masih berpusat pada guru (teacher centered), (2) pada saat pembelajaran guru cenderung menggunakan metode ceramah, tanya jawab serta penugasan, (3) kesulitan belajar yang dialami siswa saat mengikuti pembelajaran IPA di kelas terkait dengan pemahaman siswa terhadap materi yang dipelajari, sebagian besar siswa tidak dapat menjelaskan kembali konsep yang telah dipelajari.

Berdasarkan hasil wawancara yang telah dipaparkan, membuktikan bahwa permasalahan utama yang dihadapi dalam pembelajaran IPA adalah rendahnya pemahaman siswa terhadap materi yang telah dipelajari. Hal tersebut berpengaruh terhadap hasil belajar IPA siswa. Kondisi tersebut diperkuat dengan hasil pencatatan dokumen pada tanggal 8 Desember 2017 dan 9 Desember 2017 yang dilakukan di SD Gugus II Kecamatan Kubutambahan yang menerapkan Kurikulum Satuan Tingkat Pendidikan (KTSP) di kelas V. Data yang diperoleh disajikan pada tabel sebagai berikut.

Tabel 1. Data Nilai UAS IPA Kelas V di SD Gugus II Kecamatan Kubutambahan

\begin{tabular}{|c|c|c|c|c|c|c|c|c|}
\hline \multirow[b]{2}{*}{ No. } & \multirow[b]{2}{*}{ Sekolah Populasi } & \multirow[b]{2}{*}{ KKM } & \multirow[b]{2}{*}{$\begin{array}{l}\text { Rata- } \\
\text { Rata }\end{array}$} & \multirow{2}{*}{$\begin{array}{c}\text { Jumlah } \\
\text { Siswa }\end{array}$} & \multicolumn{2}{|c|}{ Tuntas } & \multicolumn{2}{|c|}{ Tidak Tuntas } \\
\hline & & & & & $\begin{array}{c}\text { Jumlah } \\
\text { Siswa }\end{array}$ & (\%) & $\begin{array}{c}\text { Jumlah } \\
\text { Siswa }\end{array}$ & (\%) \\
\hline 1 & SD N 2 Kubutambahan & 75 & 65,83 & 30 & 11 & 37 & 19 & 63 \\
\hline 2 & SD N 3 Kubutambahan & 70 & 67,32 & 38 & 21 & 55 & 17 & 45 \\
\hline 3 & SD N 4 Kubutambahan & 70 & 69,77 & 26 & 14 & 54 & 12 & 46 \\
\hline 4 & SD N 5 Kubutambahan & 75 & 71,03 & 40 & 19 & 48 & 21 & 53 \\
\hline 5 & SD N 6 Kubutambahan & 70 & 69,46 & 28 & 17 & 61 & 11 & 39 \\
\hline 6 & SD N 7 Kubutambahan & 70 & 68,80 & 25 & 15 & 60 & 10 & 40 \\
\hline
\end{tabular}

(Sumber: guru kelas V di SD Gugus II Kecamatan Kubutambahan)

Berdasarkan data pada tabel 1., menunjukkan bahwa persentase siswa yang tuntas berkisar dari $37 \%-61 \%$. Hal tersebut menunjukkan bahwa sebagian besar nilai rata-rata hasil UAS IPA yang diperoleh siswa kelas V di SD Gugus II Kecamatan Kubutambahan masih berada di bawah Kriteria Ketuntasan Minimal (KKM).

Hasil wawancara dan pencatatan dokumen diperkuat dengan hasil observasi di kelas $\mathrm{V}$ pada mata pelajaran IPA yang dilakukan pada tanggal 4 Januari 2018 hingga 10 Januari 2018 di SD Gugus II Kecamatan Kubutambahan yang menerapkan KTSP, didapatkan hasil sebagai berikut. (1) saat mengajar di kelas, guru cenderung menyampaikan materi menggunakan metode ceramah secara penuh, siswa hanya sebagai pendengar. Setelah melakukan ceramah, guru melakukan tanya jawab terkait materi yang telah disampaikan. Kemudian, guru memberikan sedikit waktu untuk siswa melakukan diskusi dengan siswa lain untuk mengerjakan tugas yang diberikan oleh guru sebagai evaluasi hasil belajar, (2) siswa cenderung pasif saat diskusi berlangsung, (3) sebagian besar siswa tidak dapat menjelaskan kembali konsep yang telah dipelajari, hal ini disebabkan karena minimnya pengetahuan siswa dalam mencari ide pokok dari perseoalan yang diberikan sehingga siswa mengalami kesulitan dalam menyampaikan materi yang sudah diajarkan, (4) saat guru menjelaskan materi banyak siswa yang bermain maupun bercanda dengan teman sebangkunya.

Berdasarkan permasalahan yang ditemukan di SD Gugus II Kecamatan Kubutambahan, maka perlu dirancang suatu pembelajaran yang menuntut siswa untuk terlibat langsung dalam pembelajaran, sehingga pemahaman siswa dan keaktifan siswa dalam menyampaikan pendapat meningkat dan hasil belajar siswa juga meningkat. Salah satu alternatif yang dapat digunakan untuk meningkatkan hasil belajar peserta didik adalah dengan menggunakan model pembelajaran examples non examples. Menurut Mariani (2015) model pembelajaran membelajarkan murid terhadap permasalahan yang ada disekitarnya melalui analisis contohcontoh berupa gambar-gambar / foto / kasus yang bermuatan masalah. Murid diarahkan untuk mengidentifikasi masalah, mencari alternatif pemecahan masalah, dan menentukan cara pemecahan masalah yang paling efektif, serta melakukan tindak lanjut. Menurut Lestiawan (2018) model pembelajaran dapat diartikan sebagai kerangka konseptual yang melukiskan prosedur sistematis dalam mengorganisasikan pengalaman belajar. Selain itu, model pembelajaran juga bertujuan untuk mencapai tujuan belajar tertentu, dan berfungsi sebagai pedoman bagi para perancang pembelajaran dan para guru untuk merencanakan dan 
melaksanakan aktivitas pembelajaran. Menurut Abidah (2014) model pembelajaran Example non Example adalah model pembelajaran yang menggunakan media gambar dalam penyampaian materi pelajaran. Dengan penggunaan gambar, siswa akan memiliki gambaran yang jelas tentang materi yang mereka pelajari. Menurut Lucky (2018) model pembelajaran Examples Non Examples merupakan model pembelajaran yang dapat menumbuhkan kepekaan siswa terhadap permasalahan yang ada di sekitar melalui analisis contohcontoh berupa gambar - gambar/foto/kasus yang bermuatan masalah. Selain itu siswa diarahkan untuk mengidentifikasi masalah, mencari alternatif pemecahan masalah, dan menentukan cara pemecahan masalah yang paling efektif, serta melakukan tindak lanjut. Menurut Shoimin (2014), model pembelajaran examples non examples merupakan model pembelajaran yang membelajarkan siswa terhadap permasalahan yang ada di sekitarnya melalui analisis contohcontoh berupa gambar-gambar, foto, dan kasus yang bermuatan masalah. Kemudian Kurniasih \& Sani (2017:31-32) menyatakan bahwa, "model ini bertujuan untuk mendorong siswa agar berpikir kritis dengan jalan memecahkan permasalahan-permasalahan yang terkandung dalam contoh-contoh gambar yang telah dipersiapkan terlebih dahulu". Penggunaan media gambar dirancang agar siswa mampu menganalisis gambar tersebut untuk kemudian dideskripsikan secara singkat perihal isi dari sebuah gambar. Dengan demikian, model ini menekankan pada konteks analisis siswa.

Selain itu, salah satu cara penyampaian materi yang dapat menjembatani antara konsep yang abstrak dan nyata/konkret adalah dengan menggunakan alat peraga. Menurut Komalasari (2010:112), "alat peraga adalah alat (benda) yang digunakan untuk memeragakan fakta, konsep, prinsip, atau prosedur tertentu agar tampak lebih nyata/konkret". Pelaksanaan pembelajaran IPA di kelas V SD dengan menggunakan alat peraga lebih menekankan pada pemberian pengalaman belajar secara langsung melalui percobaan, pengembangan keterampilan proses dan sikap ilmiah. Penggunaan alat peraga IPA dalam proses pembelajaran dapat menimbulkan rasa senang, terangsang, dan tertarik terhadap proses pembelajaran bagi siswa. Selain itu, konsep abstrak disajikan dalam bentuk konkret sehingga dapat dipahami dan dimengerti oleh siswa, serta proses pembelajaran akan lebih bermakna bagi siswa.

Tujuan penelitian ini adalah untuk mengetahui pengaruh yang signifikan model pembelajaran examples non examples berbantuan alat peraga terhadap hasil belajar IPA siswa kelas V SD di Gugus II Kecamatan Kubutambahan Tahun Pelajaran 2017/2018.

\section{Metode}

Penelitian ini merupakan penelitian eksperimen semu (quasi experiment) dengan rancangan non-equivalent post-test only control group design dapat dilihat pada gambar sebagai berikut.

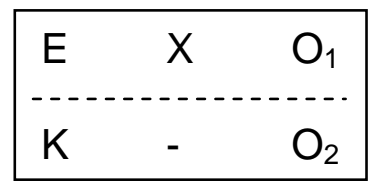

Gambar 1. Rancangan Penelitian

(dimodifikasi dari Agung, 2014)

Keterangan:

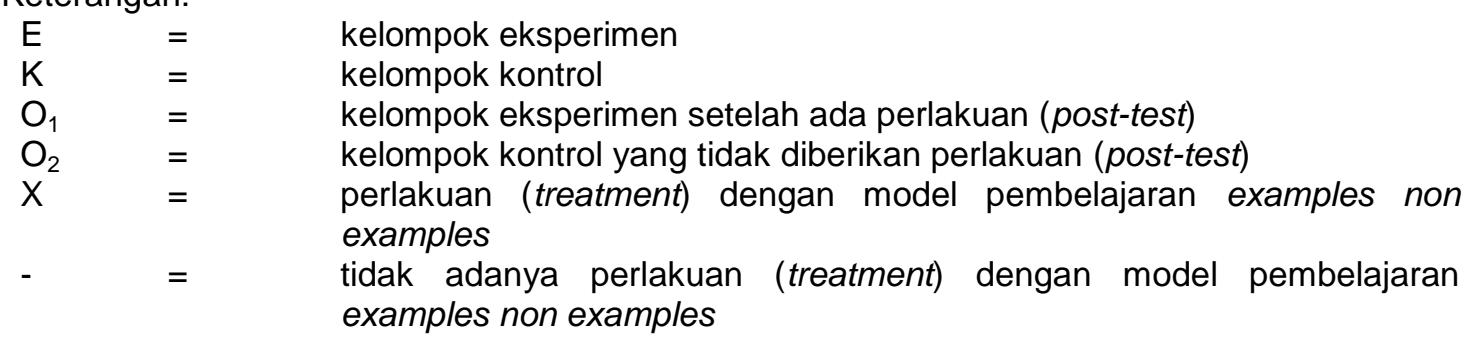

Pelaksanaan penelitian ini terdiri dari tiga tahap yaitu tahap perencanaan, tahap pelaksanaan, dan tahap pelaporan. Tahap perencanaan terdiri dari merancang perangkat pembelajaran dan instrumen yang digunakan untuk penelitian, mengonsultasikan perangkat pembelajaran dan instrumen dengan dosen pembimbing dan wali kelas, menguji instrumen 
yang digunakan untuk penelitian, melakukan analisis uji instrumen, merevisi instrumen penelitian yang telah dilakukan. Selanjutnya pada tahap pelaksanaan, pertemuan diadakan sebanyak sembilan kali pertemuan untuk memberikan treatment, dan satu kali pertemuan untuk memberikan post-test. Langkah-langkah yang dilakukan pada tahap ini yaitu: melaksanakan pembelajaran dengan memberikan perlakuan pada kelas eksperimen dengan menggunakan model pembelajaran examples non examples berbantuan alat peraga dan memberikan perlakuan pada kelas kontrol dengan tidak menggunakan model pembelajaran examples non examples berbantuan alat peraga, kemudian melaksanakan post-test pada kelompok kontrol dan kelompok eksperimen. Pada tahap pelaporan dilakukan analisis statistik deskriptif dan statistik inferensial, kemudian penyusunan laporan akhir dan penyampaian hasil penelitian pada forum ilmiah.

Populasi pada penelitian ini adalah siswa kelas V di SD Gugus II Kecamatan Kubutambahan Tahun Pelajaran 2017/2018 yang menerapkan KTSP berjumlah 187 siswa. Sebelum menentukan sampel penelitian, dilakukan uji kesetaraan populasi dengan Anava satu jalur. Berdasarkan hasil uji kesetaraan yang dilakukan pada 5 kelas populasi, pada taraf signifikansi $5 \%$ diperoleh nilai $F_{\text {hitung }}$ sebesar 1,87 dan nilai $F_{\text {tabel }}$ sebesar 2,14. Artinya, seluruh kelas memiliki kemampuan yang setara. Pengambilan sampel pada penelitian ini dilakukan dengan teknik random sampling, didapatkan hasil bahwa siswa SD N 6 Kubutambahan yang berjumlah 28 siswa sebagai kelas eksperimen dan siswa SD N 2 Kubutamabahan yang berjumlah 30 siswa sebagai kelas kontrol.

Penelitian ini melibatkan dua jenis variabel, yaitu variabel bebas dan variabel terikat. Variabel bebas yaitu satu atau lebih dari variabel-variabel yang sengaja dipelajari pengaruhnya terhadap variabel tergantung (Agung, 2014:42). Sedangkan variabel terikat yaitu variabel yang keberadaannya atau munculnya bergantung pada variabel bebas (Agung, 2014:43). Variabel bebas pada penelitian ini adalah model pembelajaran examples non examples berbantuan alat peraga dan variabel terikat pada penelitian ini adalah hasil belajar IPA.

Metode pengumpulan data yang digunakan pada penelitian ini adalah metode tes. Instrumen pengumpulan data yang digunakan adalah tes hasil belajar IPA. Jenis tes yang digunakan adalah tes objektif. Tes ini akan diberikan kepada siswa yang telah selesai mempelajari suatu materi atau pokok bahasan yang sudah diberi perlakuan. Bentuk tes pada penelitian ini adalah tes objektif bentuk pilihan ganda (multiple choice item test). Setelah instrumen tersusun, dilakukan uji coba instrumen. Uji coba instrumen penelitian dilakukan untuk mendapat gambaran mengenai dapat tidaknya instrumen tersebut digunakan sebagai instrumen penelitian. Tes yang akan diujikan adalah tes objektif yang terdiri dari 40 butir soal. Hasil uji coba tersebut akan dianalisis untuk mengetahui butir tes yang layak digunakan sebagai post-test. Instrumen yang digunakan pada penelitian ini terlebih dahulu dilakukan penilaian pakar (judges) sebelum ditetapkan sebagai instrumen penelitian, selanjutnya dilakukan uji coba dengan tujuan untuk mengetahui tingkat validitas, tingkat reliabilitas tes, tingkat kesukaran tes, dan daya beda tes.

Berdasarkan hasil pengujian instrumen, diperoleh 30 butir soal tes objektif yang digunakan untuk tes akhir (post-test). Pada penelitian ini, digunakan dua metode analisis yaitu metode analisis statistik deskriptif dan analisis statistik inferensial. Analisis statistik deskriptif dilakukan terhadap nilai rata-rata (mean), data tengah (median), data yang banyak muncul (modus), dan standar deviasi. Analisis statistik inferensial meliputi uji prasyarat analisis dan uji hipotesis. Sebelum melaksanakan uji hipotesis dilakukan uji prasyarat. Uji prasyarat ada dua yaitu uji normalitas sebaran data dan uji homogenitas varians. Untuk menguji hipotesis yang telah dirumuskan pada penelitian ini digunakan uji-t karena penelitian ini merupakan penelitian dengan membandingkan satu variabel bebas dan satu variabel terikat.

\section{Hasil dan Pembahasan}

Analisis data dilakukan pada masing-masing kelas yaitu kelas eksperimen dan kelas kontrol. Adapun hasil analisis data statistik disajikan pada tabel sebagai berikut.

Tabel 2. Rekapitulasi Deskripsi Data Hasil Belajar IPA

\begin{tabular}{lcc}
\hline \multicolumn{1}{c}{ Statisik } & Kelompok Eksperimen & Kelompok Kontrol \\
\hline Mean & 23,57 & 17,6 \\
Median & 24 & 17 \\
\hline
\end{tabular}




\begin{tabular}{lcc}
\hline Modus & 25 & 14,5 \\
Varians & 8,75 & 18,66 \\
Standar Deviasi & 2,96 & 4,32 \\
\hline
\end{tabular}

Berdasarkan Tabel 2 data hasil belajar IPA kelompok eksperimen dapat disajikan ke dalam grafik poligon pada gambar sebagai berikut.

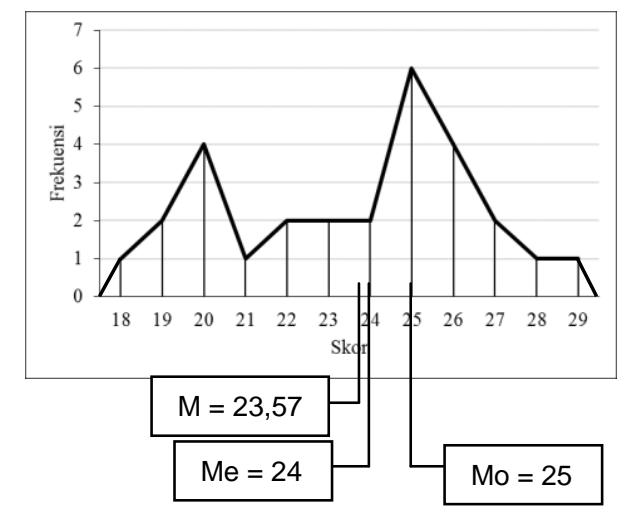

Gambar 2. Grafik Poligon Data Hasil Belajar IPA Kelompok Eksperimen

Dari data tersebut dapat diketahui bahwa modus lebih besar dari median, dan median lebih besar dari mean (Mo>Md>M). Dengan demikian, grafik poligon tersebut membentuk kurva juling negatif yang berarti sebagian besar skor cenderung tinggi. Untuk mengetahui kualitas dari variabel hasil belajar IPA siswa pada kelas eksperimen, skor rata-rata hasil belajar IPA dikonversikan dengan menggunakan kriteria rata-rata ideal dan standar deviasi ideal. Berdasarkan hasil konversi, nilai rata-rata hasil belajar IPA kelompok eksperimen adalah 23,57 terletak pada rentangan $22,5 \leq \overline{\mathrm{X}} \leq 30$ dan berada pada kategori sangat tinggi.

Sedangkan data hasil belajar IPA kelompok kontrol dapat disajikan ke dalam grafik poligon gambar sebagi berikut.

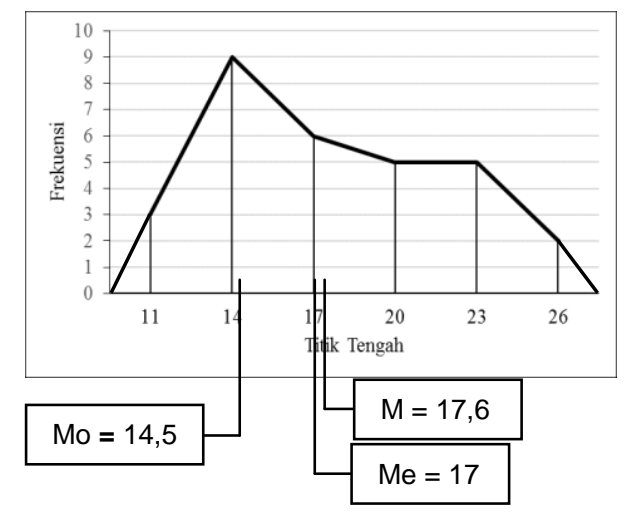

Gambar 3. Grafik Poligon Data Hasil Belajar IPA Kelompok Kontrol

Dari data tersebut dapat diketahui bahwa mean lebih besar dari median, dan median lebih besar dari modus ( $\mathrm{M}>\mathrm{Md}>\mathrm{Mo}$ ). Dengan demikian, grafik poligon tersebut membentuk kurva juling positif yang berarti sebagian besar skor cenderung rendah. Untuk mengetahui kualitas dari variabel hasil belajar IPA siswa pada kelas eksperimen, skor rata-rata hasil belajar IPA dikonversikan dengan menggunakan kriteria rata-rata ideal dan standar deviasi ideal. Berdasarkan hasil konversi, nilai rata-rata hasil belajar IPA kelompok kontrol adalah 17,6 terletak pada rentangan $17,5 \leq \overline{\mathrm{X}}<22,5$ dan berada pada kategori tinggi.

Sebelum uji hipotesis, terlebih dahulu dilakukan pengujian prasyarat yang meliputi uji normalitas sebaran data dan uji homogenitas varians. Uji normalitas sebaran data dilakukan untuk membuktikan bahwa kedua sampel tersebut berdistribusi normal. Kriteria pengujian pada taraf signifikan 5\% data terdistribusi normal jika $x^{2}$ hitung $<x^{2}$ tabel dan derajat kebebasan $\mathrm{dk}=\mathrm{k}-1$. 
Berdasarkan hasil perhitungan menggunakan rumus Chi-Kuadrat, diperoleh $\chi^{2}$ hitung hasil belajar IPA kelompok eksperimen adalah 8,5497 dan $\chi^{2}$ tabel pada taraf signifikansi $5 \%$ dan dk $=9$ adalah 16,919. Hal ini berarti, $\chi^{2}{ }_{\text {hitung }}$ hasil belajar IPA kelompok eksperimen lebih kecil dari $\chi_{\text {tabel }}^{2}\left(\chi_{\text {hitung }}^{2}<\chi_{\text {tabel }}^{2}\right.$ ), sehingga data skor hasil belajar IPA kelompok eksperimen berdistribusi normal. Sedangkan, $\chi^{2}$ hitung hasil belajar IPA kelompok kontrol adalah 4,1205 dan $\chi_{\text {tabel }}^{2}$ dengan taraf signifikansi $5 \%$ dan $\mathrm{dk}=3$ adalah 7,815 . Hal ini berarti, $\chi^{2}{ }_{\text {hitung }}$ hasil belajar IPA kelompok kontrol lebih kecil dari $\chi_{\text {tabel }}^{2}\left(\chi_{\text {hitung }}^{2}<\chi_{\text {tabel }}^{2}\right.$ ), sehingga data hasil belajar IPA kelompok kontrol berdistribusi normal. Secara ringkas, hasil uji normalitas sebaran data kelompok eksperimen dan kelompok kontrol disajikan pada tabel sebagai berikut.

Tabel 3. Hasil Uji Normalitas Sebaran Data

\begin{tabular}{|c|c|c|c|c|}
\hline No & Kelompok Data & $\chi_{\text {hitung }}^{2}$ & $\begin{array}{l}\mathrm{X}_{\text {tabel }}^{2} \text { dengan Taraf } \\
\text { Signifikansi } 5 \%\end{array}$ & Status \\
\hline 1 & Hasil Belajar IPA & 8,5497 & 16,919 & Normal \\
\hline 2 & Post-test Kontrol & 4,1205 & 7,815 & Normal \\
\hline
\end{tabular}

Selanjutnya dilakukan uji prasyarat yang kedua yaitu uji homogenitas varians. Uji homogenitas varians data hasil belajar IPA dianalisis dengan uji $\mathrm{F}$ dengan kriteria dalam pengujian ini yaitu: jika $F_{\text {hitung }}<F_{\text {tabel }}$, maka kedua kelompok data homogen. Sebaliknya jika $\mathrm{F}_{\text {hitung }}>\mathrm{F}_{\text {tabel }}$, maka kedua kelompok data tidak homogen (heterogen). Uji dilakukan pada taraf signifikan $5 \%$ dengan $\mathrm{df}_{1}=\mathrm{k}-1 \mathrm{dan}_{\mathrm{df}}=\mathrm{n}-\mathrm{k}$. Berdasarkan hasil uji $\mathrm{F}$, diperoleh $\mathrm{F}_{\text {hitung }}$ hasil belajar IPA kelompok eksperimen dan kelompok kontrol adalah 2,15, sedangkan $F_{\text {tabel }}$ pada $\mathrm{df}_{1}$ $=\mathrm{k}-1=2-1=1$, dan $\mathrm{df}_{2}=\mathrm{n}-\mathrm{k}=58-2=56$, dengan taraf signifikansi $5 \%$ adalah 4,01 . Hal ini berarti, varians data hasil belajar IPA kelompok eksperimen dan kelompok kontrol adalah homogen.

Berdasarkan hasil uji prasyarat analisis, diketahui bahwa data hasil belajar IPA kelompok eksperimen dan kelompok kontrol berdistribusi normal dan homogen. Selanjutnya, dilaksanakan pengujian hipotesis penelitian dengan menggunakan uji-t. Rumus uji-t yang digunakan adalah polled varians $\left(\mathrm{n}_{1} \neq \mathrm{n}_{2}\right)$ dengan kriteria pengujian adalah $\mathrm{H}_{0}$ ditolak jika $\mathrm{t}_{\text {hitung }}>$ $t_{\text {tabel }}$ dan $\mathrm{H}_{0}$ diterima jika $t_{\text {hitung }}<t_{\text {tabel }}$, yang mana $t_{\text {tabel }}$ diperoleh dari tabel distribusi $t$ pada taraf signifikansi $5 \%$ dengan derajat kebebasan $\mathrm{db}=\mathrm{n} 1+\mathrm{n} 2-2$. Adapun hasil analisis uji-t disajikan pada tabel sebagai berikut.

Tabel 4. Hasil Uji-t

\begin{tabular}{lcccccc}
\hline \multicolumn{1}{c}{ Kelompok } & $\mathbf{N}$ & $\mathbf{D b}$ & Mean $(\overline{\mathrm{X}})$ & $\mathbf{s}^{\mathbf{2}}$ & $\mathbf{t}_{\text {hitung }}$ & $\mathbf{t}_{\text {tabel }}$ \\
\hline Eksperimen & 28 & \multirow{2}{*}{56} & 23,57 & 8,74 & \multirow{2}{*}{6,080} & \multirow{2}{*}{2,003} \\
Kontrol & 30 & & 17,6 & 18,84 & & \\
\hline
\end{tabular}

Berdasarkan tabel 3. dapat diketahui $t_{\text {hitung }}$ lebih besar dari $t_{\text {tabel }}(6,080>2,003)$, maka $\mathrm{H}_{0}$ ditolak dan $\mathrm{H}_{1}$ diterima. Artinya, terdapat pengaruh yang signifikan model pembelajaran examples non examples berbantuan alat peraga terhadap hasil belajar IPA siswa kelas V SD di Gugus II Kecamatan Kubutambahan Tahun Pelajaran 2017/2018.

Perbedaan perlakuan pada proses pembelajaran antara kelompok eksperimen dengan kelompok kontrol, tentunya berdampak pada hasil belajar yang diperoleh siswa. Hasil uji hipotesis menunjukkan bahwa $t_{\text {hitung }}$ lebih besar dari $t_{\text {tabel }}\left(t_{\text {hitung }}>t_{\text {tabel }}\right)$, yaitu $t_{\text {hitung }}=6,080>t_{\text {tabel }}$ $=2,003$. Hal ini berarti $\mathrm{H}_{1}$ diterima dan $\mathrm{H}_{0}$ ditolak, sehingga hasil dari penelitian ini menunjukkan bahwa terdapat terdapat pengaruh yang signifikan model pembelajaran examples non examples berbantuan alat peraga terhadap hasil belajar IPA siswa kelas V SD di Gugus II Kecamatan Kubutambahan Tahun Pelajaran 2017/2018.

Besarnya pengaruh antara kelompok eksperimen yang diberikan perlakuan dengan menggunakan model pembelajaran examples non examples berbantuan alat peraga dan 
kelompok kontrol yang tidak diberikan perlakuan dengan menggunakan model pembelajaran examples non examples berbantuan alat peraga dapat dilihat dari hasil analisis statistik deskriptif antara kedua kelompok tersebut. Berdasarkan hasil analisis statistik deskriptif, ratarata hasil belajar IPA pada kelompok eksperimen adalah 23,57 yang berada pada kategori sangat tinggi dan rata-rata hasil belajar IPA pada kelompok kontrol adalah 17,60 yang berada pada kategori tinggi. Selain itu, kelompok eksperimen memiliki skor yang sebagian besar cenderung tinggi dan kelompok kontrol memiliki skor yang cenderung rendah, hal tersebut dapat dilihat dari kurva poligon masing-masing kelompok.

Hasil penelitian ini telah membuktikan hipotesis yang diajukan, yaitu terdapat terdapat pengaruh yang signifikan model pembelajaran examples non examples berbantuan alat peraga terhadap hasil belajar IPA siswa kelas V SD di Gugus II Kecamatan Kubutambahan Tahun Pelajaran 2017/2018. Hal tersebut dipengaruhi oleh beberapa hal sebagai berikut.

Pertama, model pembelajaran examples non examples lebih menekankan proses pembelajaran yang berpusat pada siswa. Hal tersebut dikarenakan siswa terlibat secara aktif untuk menggali pengetahuannya sendiri melalui belajar dalam kelompok kecil untuk menganalisis contoh-contoh berupa gambar, foto, dan kasus yang bermuatan masalah. Guru hanya sebagai fasilitator dalam pembelajaran seperti menyiapkan sumber belajar dan media pembelajaran. Temuan ini sesuai dengan pendapat yang dikemukakan oleh Rochyandi (dalam Sunggundek, 2017) yang menyatakan bahwa, model pembelajaran kooperatif tipe example non example adalah tipe pembelajaran yang mengaktifkan siswa dengan cara guru menempelkan contoh-contoh gambar yang sesuai dengan tujuan pembelajaran dan gambar lain yang relevan dengan tujuan pembelajaran, kemudian siswa disuruh untuk menganalisis gambar-gambar tersebut dan mendiskusikan hasil analisisnya sehingga siswa dapat membuat konsep yang esensial.

Kedua, model pembelajaran examples non examples merupakan model pembelajaran yang menggunakan media gambar sebagai media penyampaian materi. Penggunaan media gambar tersebut membuat proses pembelajaran menjadi lebih menarik dan kontekstual. Melalui media gambar yang berkaitan dengan materi yang dibelajarkan, siswa lebih kritis dalam menganalisis gambar-gambar untuk memecahkan masalah yang terdapat pada gambar yang disajikan oleh guru. Dengan demikian, penggunaan media gambar pada model pembelajaran examples non examples membantu siswa untuk menanamkan pengetahuan baru dari suatu materi melalui pengetahuan awal yang sudah dimiliki oleh siswa, sehingga pembelajaran menjadi lebih bermakna. Temuan ini didukung oleh penjelasan dari hasil penelitian yang dilakukan oleh Djafar (2014) yang menyatakan bahwa, penerapan model pembelajaran examples non examples dapat meningkatkan kemampuan berpikir kritis peserta didik. Peningkatan kemampuan berpikir kritis peserta didik dengan penerapan model pembelajaran examples non examples pada setiap siklus mengalami peningkatan secara perlahan-lahan.

Ketiga, dalam pembelajaran juga menggunakan alat peraga yang dapat membantu siswa memahami konsep dan membuat pembelajaran lebih menarik. Pembelajaran dengan menggunakan alat peraga lebih menekankan pada pemberian pengalaman belajar secara langsung melalui percobaan, pengembangan keterampilan proses, dan sikap ilmiah. Penggunaan alat peraga dalam proses pembelajaran dapat merangsang imajinasi siswa, meningkatkan minat dan ketertarikan siswa dalam mengikuti pembelajaran, serta proses pembelajaran akan lebih bermakna. Temuan ini didukung oleh penjelasan dari hasil penelitian yang dilakukan oleh Ujeng (2016) yang menyatakan bahwa, penggunaan alat peraga pada proses pembelajaran menempatkan siswa menjadi subjek pembelajaran (student centered learning) bukan sebagai objek pembelajaran sehingga pembelajaran tidak hanya didominasi oleh guru tetapi memberikan kesempatan kepada siswa agar terlibat langsung dalam proses pembelajaran. Serta dapat menimbulkan rasa kekeluargaan dan kebersamaan antar siswa sehingga dapat bersosialisasi dengan temannya pada saat pembelajaran berlangsung. Hal itu juga diperkuat dengan hasil penelitian yang dilakukan oleh Widiyatmoko (2013) yang menyatakan bahwa, dalam proses pembelajaran siswa menyukai kegiatan yang dilakukan di dalam kelas, terutama pada saat siswa menggunakan alat peraga secara berkelompok. Siswa menyukai pembelajaran dengan menggunakan alat peraga karena proses pembelajaran tidak membosankan dan siswa dapat bekerja sama serta berpendapat di dalam kelompok masingmasing.

Berbeda halnya dengan kelas kontrol yang dibelajarkan dengan tidak menggunakan model pembelajaran examples non examples berbantuan alat peraga, pada saat pembelajaran guru cenderung menggunakan metode ceramah, tanya jawab, dan penugasan. Pertama guru menjelaskan materi kepada siswa, kemudian guru dan siswa melakukan tanya jawab mengenai 
materi yang dipelajari, selanjutnya guru memberikan soal yang ada di buku dan siswa melakukan kegiatan diskusi kelompok untuk mengerjakan soal yang diberikan oleh guru. Setelah selesai melakukan diskusi kelompok, perwakilan kelompok menyampaikan hasil diskusi tersebut di depan kelas.

Berdasarkan temuan-temuan yang ada dalam penelitian ini, dapat dinyatakan bahwa terdapat pengaruh yang signifikan model pembelajaran examples non examples berbantuan alat peraga terhadap hasil belajar IPA siswa kelas V SD di Gugus II Kecamatan Kubutambahan Tahun Pelajaran 2017/2018.

\section{Simpulan dan Saran}

Berdasarkan hasil dan pembahasan penelitian, maka dapat disimpulkan bahwa skor rata-rata kelompok eksperimen sebesar 23,64 yang berada pada kategori sangat tinggi dan skor rata-rata kelompok kontrol sebesar 17,60 yang berada pada kategori tinggi. Hasil perhitungan uji-t untuk uji hipotesis, diperoleh $t_{\text {hitung }}$ sebesar 6,31, sedangkan $t_{\text {tabel }}$ (dengan $\mathrm{db}=$ 56 dan taraf signifikansi $5 \%$ ) adalah 2,003. Hal ini berarti, $t_{\text {hitung }}$ lebih besar dari $t_{\text {tabel }}\left(t_{\text {hitung }}>\right.$ $\left.\mathrm{t}_{\text {tabel }}\right)$, sehingga $\mathrm{H}_{0}$ ditolak dan $\mathrm{H}_{1}$ diterima. Dengan demikian, dapat disimpulkan bahwa terdapat pengaruh yang signifikan model pembelajaran examples non examples berbantuan alat peraga terhadap hasil belajar IPA siswa kelas V SD di Gugus II Kecamatan Kubutambahan Tahun Pelajaran 2017/2018.

Berdasarkan kesimpulan hasil penelitian ini dapat diajukan saran-saran sebagai berikut. Kepada siswa disarankan agar selalu memotivasi diri untuk belajar sehingga hasil belajar yang maksimal mampu dicapai, dan selalu menjaga kedisiplinan di dalam kelas. Kepada guru disarankan agar guru dapat menerapkan model pembelajaran examples non examples di kelas guna pencapaian hasil belajar siswa dan mencoba menerapkan pada materi atau pokok bahasan yang lain. Penerapan model pembelajaran ini hendaknya diimbangi dengan keaktifan guru memantau proses belajar siswa dan senantiasa memberikan arahan dan bimbingan agar kegiatan pembelajaran dapat berlangsung sesuai dengan tujuan pembelajaran yang dirancang. Kepada kepala sekolah disarankan agar hasil penelitian ini dapat dijadikan dasar-dasar pertimbangan utnutk mengambil kebijakan yang paling tepat dalam membina guru-guru untuk meningkatkan kemampuan mengelola proses pembelajaran di SD Negeri 6 Kubutambahan dan SD Negeri 2 Kubutambahan. Kepada peneliti lain disarankan agar penelitian digunakan sebagai referensi untuk melaksanakan penelitian selanjutnya atau menemukan inovasi dalam pembelajaran yang lebih bermakna dan menyenangkan bagi siswa. Untuk mengetahui kemungkinan hasil yang berbeda pada pokok bahasan lainnya, disarankan kepada peneliti selanjutnya untuk melakukan penelitian yang sejenis pada pokok bahasan yang lain.

\section{Daftar Pustaka}

Abidah, Zeni. 2014. Penggunaan Model Pembelajaran Example Non Example untuk Meningkatkan Hasil Belajar IPA Siswa Tunagrahita Kelas VII. Jurnal Ortopedagogia, VOL. 1, NO. 3, Hal. 201-211. Tersedia Pada: http://journal.um.ac.id/index.php/jo/article/view/8235 (diakses pada tanggal 18 Mei 2018).

Agung, Anak Agung Gede. 2014. Buku Ajar Metodologi Penelitian Pendidikan. Malang: Aditya Media Publishing.

Djafar, Nur Asmah. 2014. "Penerapan Model Pembelajaran Example non Example untuk Meningkatkan Kemampuan Berpikir Kritis Peserta Didik Kelas VIII.K SMP Negeri 4 Sungguminasa Kabupaten Gowa". Jurnal Bionature, Vol. 15, No. 2 (hlm. 67-80). Tersedia pada http://ojs.unm.ac.id/bionature/article/view/1551 (diakses pada tanggal 18 Mei 2018).

Komalasari, Kokom. 2010. Pembelajaran Kontekstual: Konsep dan Aplikasi. Bandung: PT Refika Aditama.

Kurniasih, Imas \& Berlin Sani. 2017. Ragam Pengembangan Model Pembelajaran. Kata Pena.

Lestiawan, Fendi, dan Arif Bintoro Johan. 2018. Penerapan Metode Pembelajaran Example Non Example untuk Meningkatkan Keaktifan dan Hasil Belajar Dasar-Dasar Pemesinan. 
Jurnal Taman Vokasi Volume 6, Nomor 1, Hal. 98-106. Tersedia Pada : http://jurnal.ustjogja.ac.id/index.php/tamanvokasi (diakses pada tanggal 18 Mei 2018).

Lucky Nurma Dianto. 2018. Penerapan Model Pembelajaran Example Non Examples terhadap Kemampuan Pemecahan Masalah Siswa SMPN 1 Tarokan 2016/2017 pada Materi Kesebangunan dan Kongruen. Simki-Techsain Vol. 02 No. 07 Hal. 1-13. Tersedia Pada : http://simki.unpkediri.ac.id/mahasiswa/file_artikel/2018/64537f22e3f2f8c2a89773337c08f f8f.pdf. (diakses pada tanggal 18 Mei 2018).

Mariani, Sri , Bachtiar A. Wahab dan F.Y. Khosmas. 2015. Penerapan Model Pembelajaran Examples and Non Examples dalam Meningkatkan Hasil Belajar Siswa. Jurnal Penelitian Pendidikan Guru Sekolah Dasar Vol. 3 No. 2 Hal. 1-15. Tersedia Pada : https://jurnalmahasiswa.unesa.ac.id/index.php/jurnal-penelitian-pgsd/article/view/15473 (diakses pada tanggal 18 Mei 2018).

Shoimin, Aris. 2014. 68 Model Pembelajaran Inovatif dalam Kurikulum 2013. Yogyakarta: ArRuzz Media.

Suastra, I Wayan. 2009. Pembelajaran Sains Terkini: Mendekatkan Siswa dengan Lingkungan Alamiah dan Sosial Budayanya. Singaraja: Universitas Pendidikan Ganesha.

Sunggudek, Nolpin. 2017. "Meningkatkan Hasil Belajar Siswa pada Mata Pelajaran IPS melalui Model Pembelajaran Examples non Examples Kelas V SDN Unu Kecamatan Bulagi Selatan". Jurnal Kreatif Tadulako Online, Vol 5, No. 9 (hlm. 193-204). Tersedia pada http://jurnal.untad.ac.id/jurnal/index.php/JKTO/article/view/3967 (diakses pada tanggal 18 Mei 2018).

Susanto, Ahmad. 2013. Teori Belajar dan Pembelajaran di Sekolah Dasar. Jakarta: Kencana.

Ujeng. 2016. "Peningkatan Hasil Belajar Siswa dengan Menggunakan Alat Peraga IPA Kelas IV SD Inpres 1 Siney". Jurnal Kreatif Tadulako Online, Vol. 4, No. 6 (hlm. 186-203). Tersedia pada http://jurnal.untad .ac.id/jurnal/index.php/JKTO/article/view/3442 (diakses pada tanggal 18 Mei 2018).

Widiyatmoko, A. 2013. "Pengembangan Perangkat Pembelajaran IPA Terpadu Berkarakter Menggunakan Pendekatan Humanistik Berbantuan Alat Peraga Murah". Jurnal Pendidikan IPA Indonesia, Vol. 2, No. 1 (hlm. 76-82). Tersedia pada https://journal.unnes.ac.id/artikel_nju/jpii/2513 (diakses pada tanggal 18 Mei 2018). 